\title{
3D Map of Dry Land Use Based Aerial Image as Learning Media in Era of Education 4.0
}

\author{
https://doi.org/10.3991/ijet.v15i07.13327 \\ Nevy Farista Aristin $(\bowtie)$ \\ Universitas Negeri Malang, Malang, Indonesia \\ Universitas Lambung Mangkurat, Banjarmasin, Indonesia \\ nevyfarista@ulm.ac.id \\ Budijanto, Didik Taryana, I Nyoman Ruja \\ Universitas Negeri Malang, Malang, Indonesia
}

\begin{abstract}
Now, this is the era of the industrial revolution 4.0, where technological innovation is developing rapidly so that education also demands to change into the era of education 4.0 immediately. The era of education 4.0, was characterized by the use of technology in the learning process. However, in reality, the learning process still facing many obstacles, one of which in terms of the use of instructional media. Learning media still use conventional and limited to Microsoft PowerPoint software which only contains writings for the presentation of dry land use material. This makes it difficult for students to understand the material presented about dry land. The purpose of this article is to develop innovative learning media with Sugiyono's development method in the form of aerial imagery-based 3D dry land maps. In this research, development is still at the product design validation stage. The results of the product design validation of 3D aerial dry land maps based on QGIS were declared to be feasible both materially and media. The results of the validation of the learning material value of 81 and the media readability value of 86 . Then the 3D map of dry landbased on aerial imagery with QGIS can be concluded feasible to be used as a learning media in the subject of land resource evaluation.
\end{abstract}

Keywords - 3D map, dry land, aerial image, Quantum GIS

\section{Introduction}

Education is a tool to produce qualified human resources. The Indonesian government is trying to improve the quality of education based on national education goals. The Law No. 20/2003 states that, the contents of the objectives of national education are to improve the quality of education in each type and level of education and to develop capabilities and shape the time and civilization of a dignified nation in order to educate the life of the nation. Therefore, the implementation of education must run effectively so that the aim of education is achieved.

Currently, the industrial revolution 4.0 is also known as an era of disruptive innovation, where innovation is developing very rapidly. The more significant challenges 
will be faced, including in the field of education so that education is demanded to change immediately. Changes in education today must be related to the industrial revolution 4.0 so it is called education 4.0. Education 4.0 is an education characterized by the use of digital technology in the learning process [1]. This system will ease the learning process continuously without the boundaries of space and time.

Therefore, the current learning process must be adapted to the 4.0 revolution era to improve or increase the quality of learning that takes place by enriching learning resources and media such as textbooks, modules, transparency overhead, film, video, television, slides, hypertext, and web [2]. One of them is by developing learning media which is a significant source to support the learning process. In the process of learning the subject of land resource evaluation, the use of instructional media is very much needed. This is because this course covers the concepts of land use and evaluates their use. For this reason, this subject need innovative learning media following the era of education 4.0.

Based on interviews with geography students who took a course in evaluating land resources, several obstacles that disturbed the learning process were found. The reason is that students are still confused to understand the material so that it makes students less enthusiastic in the learning process. In the ongoing learning process, they are still using Microsoft PowerPoint software. The contents of Microsoft PowerPoint are in the form of writings on material related to land use including dry land. This proves that the use of technology in education is still low compared to other fields such as industry, agriculture, communication [3]. So, most students want innovative and exciting learning media in explaining the contents of the material. The media itself is an inseparable part of the teaching and learning process in implementing teaching and functions to make teaching more interesting so that it can foster motivation to learn, clarify the meaning of material in students' environments to achieve teaching objectives [4-6].

Innovative learning media following the era of education 4.0 to overcome problems in the learning process in this land resource evaluation course. To overcome this problem, three-dimensional learning media related to dry land use material is needed. Simple three-dimensional media has several advantages, namely providing hands-on experience, presenting concretely and avoiding verbalism, can show the whole object both construction and how it works, can show the flow of a process clearly. But this three-dimensional media also has some weaknesses that are not able to reach targets in large numbers; storage requires ample space [7].

This three-dimensional media in the form of 3D maps for the use of dry land which can concretize abstract concepts so that they can later be easily understood. The 3D dry land map uses an application in which this media uses the use of computerized technology that is overgrowing in an era like now [8]. This is very supportive of the current conditions in which technology is developing rapidly in the industrial revolution era 4.0 .

The application used in making this 3D dry land map in QGIS (Quantum GIS). This 3D map is also based use image of the aerial. The aerial image has the potential for more detail than satellite imagery [9]. 3D maps their dry land is based on aerial imagery using QGIS will make students quickly understand the material with 3D vis- 
ualization. This is because the information provided can show the real state and detail of the map that is drawn. Students are also able to concretize land use without the need for actual fieldwork.

\section{$2 \quad$ Method}

This research is development research, which later will produce specific products. The product produced in this study is a 3D map of aerobic dry land based on the Quantum GIS application.

The research development model uses the Sugiyono model with the following stages of the model:

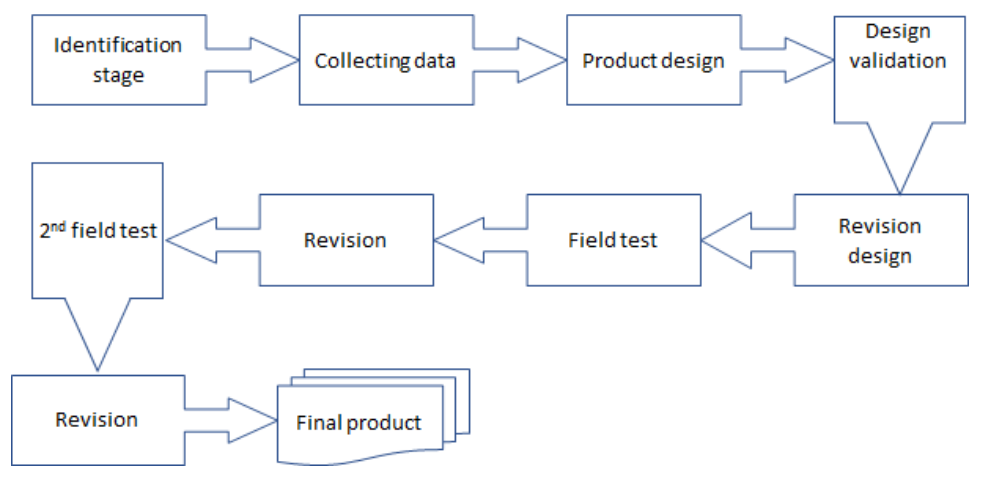

Fig. 1. Stage of Development Models [10]

This development research only carried out until the fourth stage, namely product validation. The third stage in the form of product design will produce a 3D dry land media map.

They continued in the fourth stage in the form of design validation. This stage is the last in this study. At this stage, the product form of media 3D map of dry land validated by experts such as media specialists and subject matter experts. Media and material experts will assess the product produced using the instruments provided. The instrument used by experts in the form of a questionnaire with a Likert scale containing the quality of learning media and the content of the material. The score guidelines at the validation stage by media and material experts [11] are as follows in table 1.

Table 1. Guidelines for Scoring Validation Stage

\begin{tabular}{|l|c|}
\hline \multicolumn{1}{|c|}{ Category } & Score \\
\hline Very Good / Very Decent & 5 \\
\hline Good / Decent & 4 \\
\hline Good enough / decent enough & 3 \\
\hline Poor / Inadequate & 2 \\
\hline Very Poor / Very Poor & 1 \\
\hline
\end{tabular}


The results of the validation calculated percentage calculation done by comparing the scores obtained with the maximum overall total, as follows in formula 1 :

$$
\text { Validation score }=\frac{\text { score }}{\text { maximumscors }} \times 100 \%
$$

\section{$3 \quad$ Result and Discussion}

The implementation of this research passed several main stages, they were, (1) the development phase consists of product design, product design validation, and (2) the evaluation phase consists of a revision of the design, product testing, product revision, utility testing, product revision, and final mass production products. However, this research only reached the development stage, namely, product validation.

\subsection{Preliminary study stage}

1) Identification of problems: Problems obtained when data collection by observation. The problem has been described in the background so that the development of 3D dry land maps media is needed to support learning in this 4.0 education era. 3D maps of dry land can clearly explain the form of dry land use and its distribution.

2) Data collection: Collecting data obtained from observational studies that have conducted by interviewing some unfortunate geography student state university. Also, literature studies are critical to support the contents of the $3 \mathrm{D}$ dry land media.

\subsection{Media development stage}

This stage consists of 2 stages, namely product design and product validation.

Stage of 3D map media design: The design of the 3D map media design has limitations that are:

1) The 3D map only displays the use of dry land and its distribution,

2) The making of this 3D map is intended for teaching media for the subject of land resource evaluation in the geography or related majors.

The design of the 3D dry land map media uses some data, namely Bondowoso Regency land map, Wringin District administration map, DEM imagery, and aerial imagery. This data was obtained from Digital Ina-Geoportal, ASTER DEMNAS USGS Earth Explorer, and Balitbang of Bondowoso Regency. These data will be processed using the Quantum GIS (QGIS) application. Processing to produce 3D maps of dry land is passed through several stages, which are explained as follows in fig.2. 


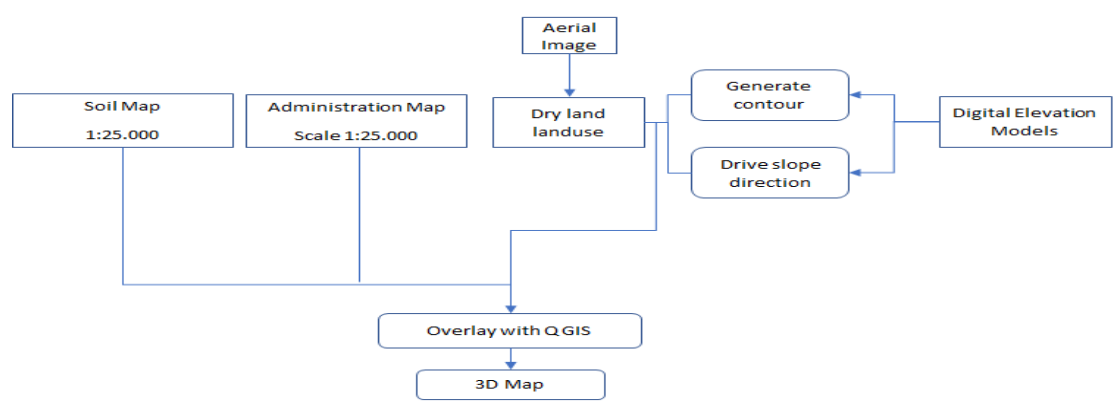

Fig. 2. Flowchart to Make 3D Map of Dry Land Use

Based on the plot of making 3D maps of dry land above, it can be seen that aerial image data used to determine the type of land use in the area. When aerial imagery data in the form of land use then added to DEM data, the land produces more information related to contours and slopes. Other data such as land type data and regional administration are also needed so that the land in the area is more detailed in the information produced.

The results of processing from aerial imagery with the application of QGIS obtained the pattern of dry land use and its use from the land itself (fig 3).

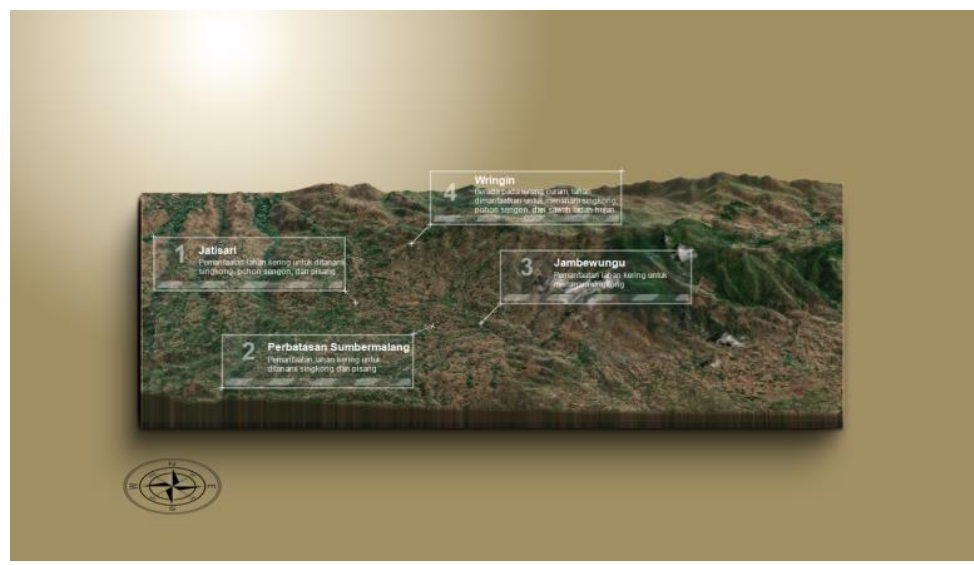

Fig. 3. 3D Map of Dry Land Distribution in Wringin District, Bondowoso, Indonesia

For the first stage, the 3D map presents the distribution of dry land in the Wringin District, Bondowoso Regency, represented by four villages (fig 4-6). The four villages are Jatisari, Sumbermalang, Jambewungu, and Wringin Villages. The distribution of dry land dominates the area in Wringin District. This supported by the fact that land use in the Wringin District is in the form of 3601.93 Ha of dry land [3] Topography of Wringin District is mainly in the form of mountains and hills with a slope of $3-15 \%$ and $16-40 \%$. 


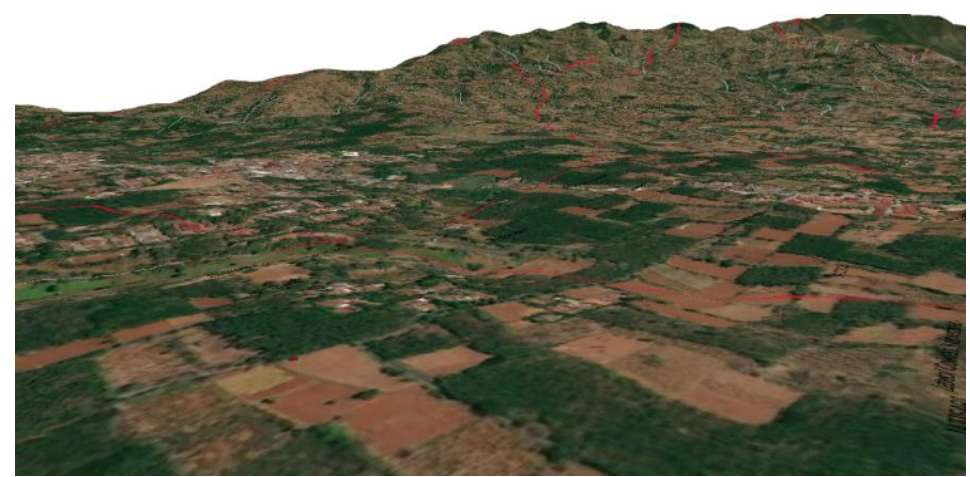

Fig. 4. 3D Map of Dry Land in Sumbermalang Village Location Bondowoso, Indonesia

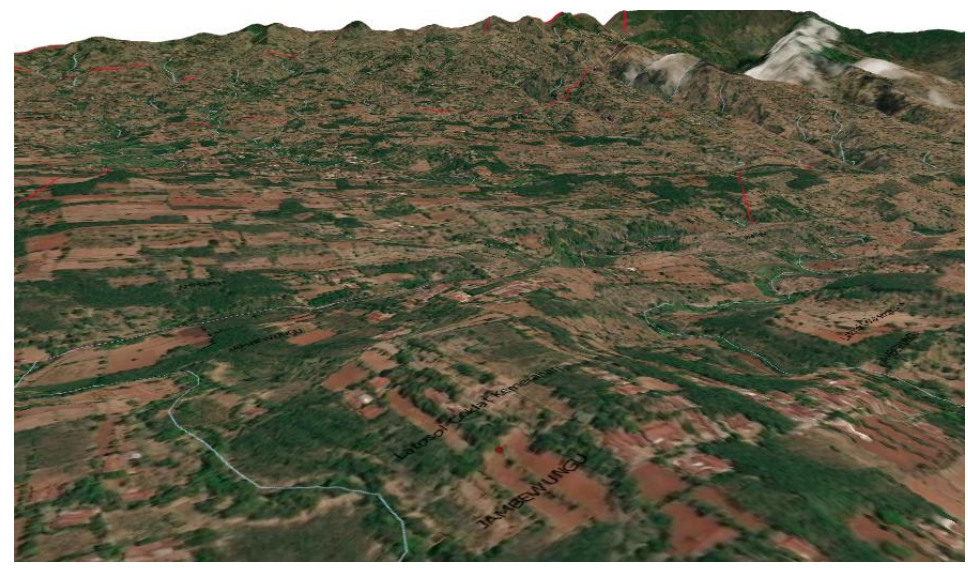

Fig. 5. 3D Map of Dry Land in the Location of Jambewungu Village, Bondowoso, Indonesia

Based on the four 3D maps of dry land available (fig 3-6), it can be seen in detail how the topography, slope, and shape of dry land use in the Wringin District area of Bondowoso Regency. On the 3D map of dry land in each village were given information on the type of land. This is very important later in order to be able to manage and utilize land according to the type and nature of the existing land so that it can be optimally cultivated. 


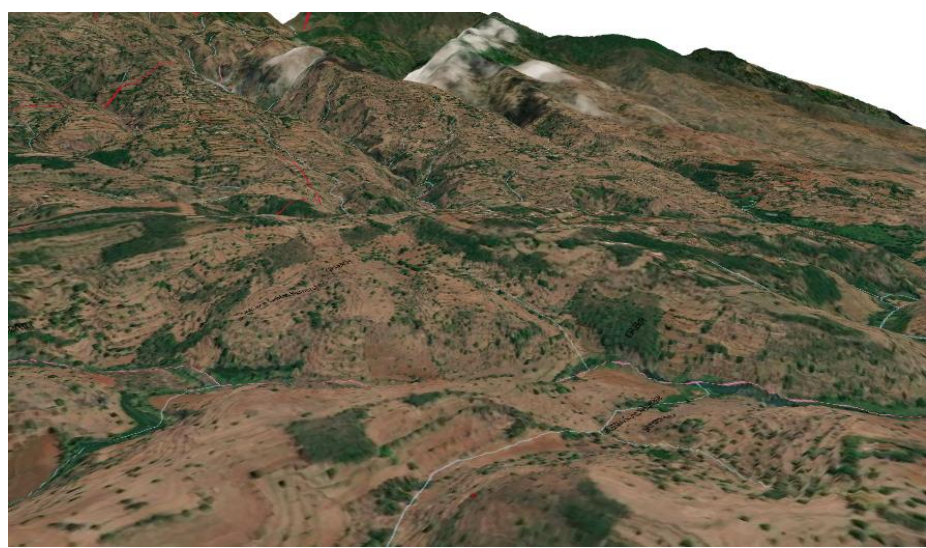

Fig. 6. 3D Map of Dry Land in Wringin Village Location Bondowoso, Indonesia

Design validation: Design validation is a process for assessing product design carried out by experts who are experienced with the product design. It aims to make the strengths and weaknesses of the design of products discovered [4]. The product design validation will be carried out by material experts and media experts. Material validator is a person who is an expert on material about the use of dry land. For this reason, the material validator is Sadewa Purba Sejati, lecturer in physical geography in the Department of Geography, Universitas Amikom Yogyakarta. Media experts who act as validators are instructors of instructional media about dry land use. The media validators is Kunthum Ria Anggraheny, a lecturer of Geography Education study program at Universitas Widya Dharma, Klaten.

Table 2. Results of learning material and media readability validation

\begin{tabular}{|l|l|l|}
\hline \multicolumn{1}{|c|}{ Validator } & \multicolumn{1}{|c|}{ Suggestion } & \multicolumn{1}{c|}{ Revision } \\
\hline Material expert & $\begin{array}{l}\text { More detailed physiographic information for } \\
\text { each region }\end{array}$ & More detailed map information \\
\cline { 2 - 3 } & $\begin{array}{l}\text { Added information on what plants potentially } \\
\text { planted in dry land with sample images }\end{array}$ & $\begin{array}{l}\text { Provides images of potential plants } \\
\text { that can plant on dry land }\end{array}$ \\
\hline Media expert & The writing font on the map is still unclear & $\begin{array}{l}\text { The font of the writing on the 3D } \\
\text { map will be corrected and clarified }\end{array}$ \\
\cline { 2 - 3 } & More information displayed & $\begin{array}{l}\text { Show more information on a 3D } \\
\text { dry land map }\end{array}$ \\
\hline
\end{tabular}

The results of the validation conducted by two validators on aerial imagery based 3D dry land maps with the QGIS application are valid for the materials, methods, and media. The media validator gave the score of 86 and the score of 81 from material expert. From two validators evaluations, a score above 80 was categorized and declared valid. However, the validator still provides suggestions for improvement so that the 3D map media is better, as follows in table 2 .

Suggestions given by media experts and material experts are beneficial for improving the 3D dry land media map. For the evaluation phase in this research, the development will be continued based on the results of this study. The development of in- 
structional media in the subject of land resource evaluation will not be separated from multimedia. Especially now, an era where technology is developing very rapidly called the 4.0 era. For this reason, education nowadays must be able to develop media by utilizing computerized technology [14] that is interactive and innovative in the learning process so that it is easier for the students to understand the material described in the educational era 4.0 [15].

\section{Conclusion}

The development of innovative media in the era of education 4.0 is now required in the learning process. One of the developments of innovative media in the field of land resource evaluation is aerial image of based 3D maps with QGIS applications. With this 3D map, students can directly concretize what is in their minds. Students will not be confused imagining how dry land forms and their direct use. When there is practicum in the field, students already understand what they explain. The design of the 3D dry land map was validated by two experts in the field of material and media. The results of these two experts are above 80 . This shows that the 3D map media is feasible to enter the next stage of product trials.

\section{$5 \quad$ References}

[1] Siriwatchana Kaeophanuek, Jaitip Na-Songkhla, Prachyanun Nilsook. 2019. A Learning Process Model to Enhance Digital Literacy using Critical Inquiry through Digital Storytelling (CIDST). International Journal of Emerging Technologies in Learning. Vol 13 Issue 3 pp. 22-37 https://doi.org/10.3991/ijet.v14i03.8326

[2] I. W. Santyasa, Landasan Konseptual Media Pembelajaran, Klungkung: Universitas Pendidikan Ganesha, 2007.

[3] U. Tirtaraharja and S.L. La Sulo, Pengantar Pendidikan, Jakarta: PT. Rineka Cipta, 2005.

[4] A. Arsyad, Media Pembelajaran, Jakarta: PT Raja Grafindo Persada, 2011.

[5] D. Indriana, Ragam Alat Bantu Media Pembelajaran, Yogyakarta: Diva Press Jogjakarta, 2011.

[6] N. Sudjana and Rivai, Penilaian Proses Hasil Belajar Mengajar, Bandung: Remaja Rosda Karya, 2001.

[7] Moedjiono, Media Pendidikan III: Cara Pembukaan Media Pendidikan, Jakarta: P3G Depdikbud, 1981.

[8] Samaa Alawi Al Hashimi, Ameena Abbas Al Muwali, Yasmina Eid Zaki, Nasser Abdulla Mahdi. 2019. The Effectiveness of Social Media and Multimedia-Based Pedagogy in Enhancing Creativity among Art, Design, and Digital Media Students. International Journal of Emerging Technologies in Learning. Vol 14 Issue 21 pp. 176-190. https://doi.org/10. 3991/ijet.v14i21.10596

[9] W. Bakker, L. Lucas, J. Jansen, Weir, Ben G.H, Gorte, P. Christine, W. Tsehaie, A. H. John and V. R. Colin, "Principles of Remote Sensing: An introductory textbook," in The International Institute for Aerospace Survey and Earth Science, Netherlands, 2000.

[10] Sugiyono, Metode Penelitian Pendidikan, Bandung: Alfabeta, 2011.

[11] A. Sudjiono, Pengantar Statistik Pendidikan, Jakarta: PT Raja Grasindo Persada, 2006. 
[12] BPS Kabupaten Bondowoso, Kecamatan Wringin Dalam Angka Tahun 2018, Bondowoso: BPS Kabupaten Bondowoso, 2018. https://doi.org/10.32528/agribest.v2i1.1380

[13] Sugiyono, Metode Penelitian Pendidikan Pendekatan Kuantitatif, Kualitatif, dan R\&D. Bandung: Alfabeta, 2009.

[14] C. U. Affandi and H. Wibawanto, "Pengembangan Media Animasi Interaktif 3 (Tiga) Dimensi Sebagai ALat Bantu Ajar Mata Pelajaran IPA Kelas VII Menggunakan Blender Game Engine," Jurnal Teknik Elektro, vol. 7, no. 2, pp. 62-70, 2015.

[15] Satria Fadil Persada, Bobby Ardiansyah Miraja, Reny Nadlifatin. 2019. Understanding the Generation Z Behavior on D-Learning: A Unified Theory of Acceptance and Use of Technology (UTAUT) Approach. International Journal of Emerging Technologies in Learning. Vol 14 Issue 3 pp. 20-33. https://doi.org/10.3991/ijet.v14i05.9993

\section{Acknowledgement}

Thank you to the Ministry of Research and Higher Education who provided BPPDN Scholarships in 2017.

\section{$7 \quad$ Authors}

Nevy Farista Aristin, is a student of doctoral program in Geography Education Department, Faculty of Social Sciences, Universitas Negeri Malang. She is a member of lecturer in Geography Education, Faculty of Teacher Training and Education, Universitas Lambung Mangkurat, Banjarmasin, South Kalimantan. Her main research interest's regional development studies and geography education.

Budijanto, is member of lecturer in Geography Department, Faculty of Social Science, Universitas Negeri Malang. He is a Professor of Demography Subject. His main research interests studies of international immigration labour.

Didik Taryana is member of lecturer in Geography Department, Faculty of Social Science, Universitas Negeri Malang. His main research interests island and water conservation, hydrology and physical geography.

I Nyoman Ruja, is a member of lecturer in Social Studies, Faculty of Social Science, Universitas Negeri Malang.His main research interests is sociology studies.

Article submitted 2020-01-21. Resubmitted 2020-02-09. Final acceptance 2020-02-16. Final version published as submitted by the authors. 